\title{
Penerapan Model Pembelajaran Berbasis Proyek Untuk Meningkatkan Aktivitas dan Hasil Belajar Pada Materi Sistem Gerak Pada Tumbuhan
}

\author{
Chritstofel A. L. Mananeke ${ }^{1 *}$, Zusje W. M. Warouw ${ }^{2}$ \\ 1,2 Jurusan Pendidikan IPA, FMIPA, Universitas Negeri Manado \\ *e-mail: ofelmananeke1995@gmail.com
}

\begin{abstract}
Abstrak. Penelitian ini bertujuan untuk melihat keaktifan siswa selama pelaksanaan pembelajaran IPA materi sistem gerak pada tumbuhan serta meningkatkan hasil belajar dengan model pembelajaran berbasis proyek. Penelitian ini menggunakan penelitian tindakan kelas. Populasi dalam penelitian ini adalah siswa kelas VIII SMP Negeri 3 Likupang Barat yang terdiri dari 2 kelas yakni VIII-A dan VIII-B. Pengumpulan data dilakukan dengan observasi, wawancara serta dokumentasi. Hasil analisis data menunjukkan selama pelaksanaan pembelajaran berbasis proyek terlihat keaktifan siswa yakni 13 peserta didik (43,33\%) dikategorikan sangat aktif (keberanian untuk mengajukan pertanyaan atau mengemukakan pendapat serta kreatifitas belajar dalam kelompok terlihat sangat tinggi), 11 peserta didik (36,66\%) dikategorikan aktif (mengajukan pertanyaan atau menjawab pertanyaan serta mengemukakan pendapat dikategorikan aktif meskipun melakukan dengan dorongan dari guru) dan 6 peserta didik (20\%) dikategorikan cukup aktif (meskipun terlibat dalam proses pembelajaran namun meraka masih malu atau sibuk dengan kegiatan masing-masing) dan untuk hasil belajar $24(80 \%)$ peserta didik dinyatakan tuntas dan hanya $6(20 \%)$ siswa hasil belajarnya belum tuntas.
\end{abstract}

Kata kunci: pembelajaran berbasis proyek, keaktifan siswa, hasil belajar

\begin{abstract}
This study aims to see the activeness of students during the implementation of science learning material on motion systems in plants and to improve learning outcomes with a project-based learning model. This research uses classroom action research. The population in this study were class VIII students of SMP Negeri 3 Likupang Barat, which consisted of 2 classes, namely VIII-A and VIII-B. Data was collected by observation, interviews and documentation. The results of data analysis showed that during the implementation of project-based learning, it was seen that the activeness of students, namely 13 students (43.33\%) were categorized as very active (the courage to ask questions or express opinions and the creativity of learning in groups was very high), 11 students (36.66) \%) were categorized as active (asking questions or answering questions and expressing opinions were categorized as active even though they did it with encouragement from the teacher) and 6 students (20\%) were categorized as quite active (even though they were involved in the learning process but they were still shy or busy with their respective activities) and for learning outcomes $24(80 \%)$ students were declared complete and only $6(20 \%)$ students had incomplete learning outcomes.
\end{abstract}

Keywords: project-based learning, student activity, learning outcomes

Diterima 13 Oktober 2021 | Disetujui 17 Desember 2021 | Diterbitkan 31 Desember 2021

\section{PENDAHULUAN}

. Proses pembelajaran yang efektif memerlukan peranan guru dan siswa dimana ada interaksi dua arah, peserta didik terlibat aktif didalamnya, seperti mengemukakan pendapat mereka sendiri, menghargai pendapat teman, kerja sama dalam kelompok, memberikan ide atau 
pemikiran kritis, memperhatikan penjelasan dari guru, bertanya serta memberikan jawaban atas pertanyaan yang ada. Dalam pembelajaran IPA diperlukan keaktifan siswa selama proses pembelajaran berlangsung. Model pembelajaran berbasis proyek ini memfokuskan pada aktivitas peserta didik yang berupa pengumpulan informasi yang dapat diaplikasikan dalam kehidupan sehari-hari.

Pembelajaran berbasis proyek merupakan metode belajar yang menggunakan masalah sebagai langkah awal dalam pengumpulan dan mengintegrasikan pengumpulan baru berdasarkan pengalamannya dalam beraktifitas secara nyata. Pembelajaran berbasis proyek yaitu pembelajaran inovatif, dan lebih menekankan pada belajar kontekstual melalui kegiatankegiatan yang kompleks. Fokus pembelajaran pada prinsip dan konsep dari suatu disiplin ilmu, melibatkan siswa melakukan investigasi pemecahan masalah dan kegiatan-kegiatan tugas bermakna, memberi kesempatan pembelajar bekerja secara mandiri dalam mengelolah pengetahuan mereka sendiri dan menghasilkan produk nyata (Wena, 2011).

Pembelajaran berbasis proyek menfokuskan pada aktifitas peserta didik yang berupa pengumpulan informasi dan pemanfaatannya untuk menghasilkan sesuatu bagi kehidupan peserta didik itu sendiri ataupun bagi orang lain, namun tetap terkait dengan kompetensi dasar dalam kurikulum. Pembelajaran berbasis proyek didukung oleh teori belajar konstruktivistik. Teori belajar yang mendapat dukungan luas yang bersandar pada pemikiran bahwa peserta didik membangun pengetahuannya sendiri dalam konteks pengalamannya sendiri.

Tujuan model pembelajaran berbasis proyek diantaranya: 1) Peserta didik memperoleh manfaat yang bisa dirasakan lansung dari pelajaran yang mereka ikuti bagi kehidupan sehari-hari. 2) Peserta didik bisa berkreasi, berinovasi dan mengembangkan potensinya sendiri dalam bentuk kegiatan atau karya dari proses pembelajaran yang telah dilakoninya, baik secara sendiri ataupun berkelompok. 3) Potensi peserta didik bisa lebih aktif dan teroptimalkan, tidak hanya poteni intelektual tetapi juga fisik, emosi, sosial, dan spiritual. 4) Peserta didik dapat mengembangkan kemampuan dan keterampilannya didalam mengelolah dan memanfaatkan sumber, bahan dan potensi-potensi lingkungan, masyarakat, dan budayanya untuk menjadi sesuatu yang bermakna bagi dirinya dan bagi orang lain (Kosasih, 2014).

Hasil penelitian dari Wardani (2017) menyatakan bahwa model pembelajaran berbasis proyek dapat meningkatkan kinerja guru dalam proses belajar mengajar serta meningkatkan hasil belajar siswa. Hasil penelitian dari Sarwono \& Sugiharto (2017) menyatakan bahwa model pembelajaran berbasis proyek lebih cocok dalam membangkitkan psikomotorik siswa kaitannya dengan kemampuan untuk berprilaku baik terhadap lingkungan.

$\begin{array}{ccc}\text { Hasil penelitian dari } & \text { Nurfitriyanti } \\ \text { (2016) } & \text { menyatakan } & \text { hendaknya }\end{array}$ pembelajaran berbasis proyek hendaknya dijadikan alternatif dalam menyampaikan pembelajaran karena memberikan pengaruh positif terhadap kemampuan pemecahan masalah. Hasil penelitian lainnya juga dari Dewi (2012) menyatakan bahwa pembelajaran berbasis proyek dapat meningkatkan motivasi siswa dilihat dari peningkatan rata-rata skor motivasi belajar siswa. Sedangkan menurut Efrimal, Kurnia, \& Wasidi (2017) penerapan model pembelajaran berbasis proyek mampu meningkatkan kecermatan siswa.

Tujuan dari penelitian ini adalah melihat keaktifan dan hasil belajar peserta didik dengan menerapkan model pembelajaran berbasis proyek.

\section{METODE PENELITIAN}

Rancangan penelitian yang digunakan adalah penelitian tindakan kelas meliputi empat alur yaitu: perencanaan tindakan, pelaksanaan tindakan, observasi, dan refleksi.

Tempat penelitian ini dilakukan di SMP Negeri 3 Likupang Barat. Penelitian 
ini dilakukan pada semester ganjil tahun ajaran 2019/2020. Data yang diperoleh dari peserta didik kelas VIII dan salah satu guru IPA kelas VIII.

Teknik pengumpulan data yang dilakukan berupa pengamatan (observasi), wawancara (interview), dan dokumentasi. Teknik analisis data dalam penelitian ini terdiri dari: 1) Reduksi data, yaitu memilih hal-hal pokok yang sesuai dengan fokus penelitian. 2) Penyajian data, yaitu sekumpulan informasi yang tersusun memungkinkan adanya penarikan kesimpulan dan pengambilan tindakan. 3) Penarikan kesimpulan. Setelah data disajikan maka dilakukan penarikan kesimpulan atau verifikasi. Verifikasi dapat dilakukan dengan keputusan, didasarkan pada reduksi data dan penyajian data yang merupakan jawaban atas masalah yang diangkat dalam penelitian.

Indikator keberhasilan dalam penelitian ini adalah peningkatan aktivitas dan hasil belajar peserta didik ditandai dengan tercapainya Kriteria Ketuntasan Minimum (KKM) dengan perincian, perorangan yaitu tercapainya KKM (70) dam klasikal yaitu memperoleh nilai di atas KKM mencapai $80 \%$.

\section{HASIL DAN PEMBAHASAN}

Hasil yang diperoleh pada siklus I, dalam proses pembelajaran, terdapat 9 peserta didik yang keaktifannya cukup aktif dimana 4 peserta didik hanya mainmain, keluar masuk kelas tanpa izin, mengganggu teman dan 5 peserta didik lainya hanya diam atau masih malu. 14 peserta didik terlihat aktif meskipun didorong oleh peneliti sebagai guru agar berani dalam menjawab pertanyaan ataupun mengajukan pendapat namun ada beberapa masih kurang percaya diri akan tanggapan atas pertanyaan yang ada dan 7 peserta didik lainnya sangat aktif tanpa malu dan sangat percaya diri akan jawaban atas pertanyaan yang ada atau berani dalam mengajukan pertanyaan serta terlibat aktif dalam belajar kelompok (adanya kekompakan dan kerjasama). Data hasil penilaian keaktifan siswa pada siklus I dapat dilihat pada Tabel 1.
Tabel 1. Keaktifan siswa siklus I

\begin{tabular}{lll}
\hline Keaktifan & Frekuensi & Persentase \\
\hline Sangat aktif & 7 & $23,33 \%$ \\
Aktif & 14 & $46,66 \%$ \\
Cukup aktif & 9 & $30 \%$ \\
Total & 30 & $100 \%$ \\
\hline
\end{tabular}

Berdasarkan Tabel 1, dapat dilihat bahwa persentase keaktifan tertinggi sebesar 46,66\% siswa yang tergolong aktif.

Proyek yang dibuat berupa karya yang kemudian dipresentasikan oleh peserta didik. Penilaiannya dilakukan mulai dari perencanaan, pelaksanaan, hasil akhir proyek serta penyajian proyek (presentasi). Keterbatasan alat dan bahan menjadi kendala sehingga waktu yang diperlukan melebihi waktu yang sudah ditentukan sebelumnya. Dalam pelaksanaannya terlihat 6 peserta didik yang hanya sibuk dengan kegiatan masing-masing, diam, serta mengharapkan keterampilan dari teman sekelompoknya. Deskripsi data hasil penilaian proyek pada siklus I dapat dilihat pada Tabel 2.

Tabel 2. Deskripsi penilaian proyek siklus I

\begin{tabular}{llllll}
\hline Penilaian & $\mathrm{N}$ & Min & Maks & $\begin{array}{l}\text { Rata- } \\
\text { rata }\end{array}$ & $\begin{array}{l}\text { Simpangan } \\
\text { baku }\end{array}$ \\
\hline Proyek & 30 & 2,75 & 4,00 & 3,42 & 0,39 \\
\hline
\end{tabular}

Berdasarkan Tabel 2, secara sistematis capaian optimum yang diperoleh peserta didik kelas VIII SMP Negeri 3 Likupang Barat berdasarkan penilaian proyek, yaitu nilai tertinggi 4,00 dan nilai terendah 2,75 dengan nilai ratarata 3,42 . Secara keseluruhan capaian optimum berdasarkan penilaian proyek pada siklus I dapat dilihat pada Tabel 3.

Tabel 3. Penilaian proyek siklus I

\begin{tabular}{lll}
\hline Capaian optimum & Frekuensi & Persentase \\
\hline A & 2 & $7 \%$ \\
A- & 6 & $20 \%$ \\
B+ & 14 & $46 \%$ \\
B & 2 & $7 \%$ \\
B- & 6 & $20 \%$ \\
Total & 30 & $100 \%$ \\
\hline
\end{tabular}


Berdasarkan Tabel 3, capaian optimum dari 30 peserta didik kelas VIII 3 Likupang, yakni 2 (7\%) peserta didik capaian optimum A, 6 (20\%) peserta didik capaian optimum A-, $14(46 \%)$ peserta didik capaian optimum $\mathrm{B}+, 2(7 \%)$ peserta didik capaian optimum B-, dan $6(20 \%)$ peserta didik capaian optimum $B$.

Hasil belajar peserta didik dilihat dari nilai yang diperoleh dari pengerjaan lembar instrumen tes berupa soal tentang sistem gerak pada tumbuhan. Siswa dinyatakan lulus jika mencapai nilai $\geq 70$. Deskripsi penilaian hasil belajar pada siklus I dapat dilihat pada Tabel 4.

Tabel 4. Deskripsi hasil belajar siklus I

\begin{tabular}{llllll}
\hline Penilaian & N & Min & Maks & $\begin{array}{l}\text { Rata- } \\
\text { rata }\end{array}$ & $\begin{array}{l}\text { Simpangan } \\
\text { baku }\end{array}$ \\
\hline $\begin{array}{l}\text { Hasil } \\
\text { belajar }\end{array}$ & 30 & 58 & 92 & 66,8 & 7 \\
\hline
\end{tabular}

Berdasarkan Tabel 4, secara sistematis capaian optimum yang diperoleh peserta didik kelas VIII SMP Negeri 3 Likupang Barat berdasarkan penilaian hasil belajar, yaitu nilai tertinggi 92 dan nilai terendah 58 dengan nilai rata-rata 66,8 . Secara keseluruhan capaian optimum berdasarkan penilaian hasil belajar pada siklus I dapat dilihat pada Tabel 5 .

Tabel 5. Hasil belajar siklus I

\begin{tabular}{llll}
\hline Nilai & Predikat & Frekuensi & Persentase \\
\hline $89-100$ & A & 1 & $3 \%$ \\
$79-89$ & B & 1 & $3 \%$ \\
$70-79$ & C & 8 & $27 \%$ \\
$<70$ & D & 20 & $67 \%$ \\
Total & & 30 & $100 \%$ \\
\hline
\end{tabular}

Berdasarkan Tabel 5, capaian optimum dari 30 peserta didik kelas VIII 3 Likupang, yakni $2(6 \%)$ peserta didik mendapatkan nilai diatas KKM (70) dengan perincian 1 (3\%) peserta didik mendapatkan predikat nilai A dan 1 (3\%) peserta didik mendapatkan predikat nilai $\mathrm{B}, \quad 8(27 \%)$ peserta didik mendapatkan predikat nilai $\mathrm{C}$ dan 20 (67\%) peserta didik mendapatkan predikat nilai $\mathrm{D}$.

Hasil yang diperoleh pada siklus II, pelaksanaan penelitian berlangsung di kelas VIII SMP Negeri 3 Likupang Barat selama pembelajaran IPA dengan model pembelajaran berbasis proyek. Peserta didik dibagi menjadi 5 kelompok yang kemudian diberikan lembar kerja yang akan dilakukan seperti melakukan pengamatan terhadap tumbuhan putri malu dan pada pertumbuhan kecambah kacang hijau. Setiap kegiatan yang dilakukan akan diambil dokumntasi yang nantinya akan dipresentasikan didepan kelas berupa proyek. Tiap kelompok mempresentasikan hasil proyeknya di depan kelompok lain. Terlihat 23 peserta didik (76\%) yang aktif dan 7 lainnya (24\%) masih pasif (sibuk dengan kegiatan masing-masing dan masih malu bertanya atau mempresentasikan hasil proyek). Data hasil penilaian keaktifan siswa pada siklus II dapat dilihat pada Tabel 6 .

Tabel 6. Keaktifan siswa siklus II

\begin{tabular}{lll}
\hline Keaktifan & Frekuensi & Persentase \\
\hline Sangat aktif & 13 & $43,33 \%$ \\
Aktif & 11 & $36,66 \%$ \\
Cukup aktif & 6 & $20 \%$ \\
Total & 30 & $100 \%$ \\
\hline
\end{tabular}

Berdasarkan Tabel 6, keaktifan dari 30 peserta didik kelas VIII SMP Negeri 3 Likupang Barat, yakni 13 peserta didik $(43,33 \%)$ dikategorikan sangat aktif (keberanian untuk mengajukan pertanyaan atau mengemukakan pendapat serta kreatifitas belajar dalam kelompok terlihat sangat tinggi), 11 peserta didik $(36,66 \%)$ dikategorikan aktif (mengajukan pertanyaan atau menjawab pertanyaan serta mengemukakkan pendapat dikategorikan aktif meskipun melakukan dengan dorongan dari guru) dan 6 peserta didik (20\%) dikategorikan cukup aktif (meskipun terlibat dalam proses pembelajaran namun meraka masih malu atau sibuk dengan kegiatan masing-masing). Deskripsi penilaian proyek pada siklus II dapat dilihat pada Tabel 7.

Tabel 7. Deskripsi penilaian proyek siklus II

\begin{tabular}{llllll}
\hline Penilaian & $\mathrm{N}$ & Min & Maks & $\begin{array}{l}\text { Rata- } \\
\text { rata }\end{array}$ & $\begin{array}{l}\text { Simpangan } \\
\text { baku }\end{array}$ \\
\hline Proyek & 30 & 3,16 & 4,00 & 3,64 & 0,23 \\
\hline
\end{tabular}


Berdasarkan Tabel 7, secara sistematis capaian optimum yang diperoleh peserta didik kelas VIII SMP Negeri 3 Likupang Barat berdasarkan penilaian proyek, yaitu nilai tertinggi 4,00 dan nilai terendah 23,16 dengan nilai rata-rata 3,64. Secara keseluruhan capaian optimum berdasarkan penilaian proyek pada siklus II dapat dilihat pada Tabel 8.

Tabel 8. Penilaian proyek siklus II

\begin{tabular}{lll}
\hline Capaian optimum & Frekuensi & Persentase \\
\hline A & 5 & $16,66 \%$ \\
A- & 15 & $50 \%$ \\
B+ & 8 & $26,66 \%$ \\
B & 2 & $6,66 \%$ \\
Total & 30 & $100 \%$ \\
\hline
\end{tabular}

Berdasarkan Tabel 8, capaian optimum dari 30 peserta didik kelas VIII 3 Likupang, yakni 5 peserta didik (16,66\%) capaian optimum A, 15 peserta didik $(50 \%)$ capaian optimum A-, 8 peserta didik $(26,66 \%)$ capaian optimum $\mathrm{B}+$ dan 2 peserta didik $(6,66 \%)$ capaian optimum B.

Hasil belajar dilihat dari capaian nilai yang diperoleh oleh tiap peserta didik. Peserta didik dikatakan berhasil jika mendapatkan nilai hasil belajar $\geq 70$. Deskripsi pencapaian hasil belajar pada siklus II dapat dilihat pada Tabel 9.

Tabel 9. Deskripsi hasil belajar siklus II

\begin{tabular}{llllll}
\hline Penilaian & $\mathrm{N}$ & Min & Maks & $\begin{array}{l}\text { Rata- } \\
\text { rata }\end{array}$ & $\begin{array}{l}\text { Simpangan } \\
\text { baku }\end{array}$ \\
\hline $\begin{array}{l}\text { Hasil } \\
\text { belajar }\end{array}$ & 30 & 64 & 98 & 66,8 & 10 \\
\hline
\end{tabular}

Berdasarkan Tabel 9, secara sistematis capaian optimum yang diperoleh peserta didik kelas VIII SMP Negeri 3 Likupang Barat berdasarkan penilaian hasil belajar, yaitu nilai tertinggi 98 dan nilai terendah 64 dengan nilai rata-rata 66,8 . Secara keseluruhan capaian optimum berdasarkan penilaian hasil belajar pada siklus II dapat dilihat pada Tabel 10.
Tabel 10. Hasil belajar siklus II

\begin{tabular}{llll}
\hline Nilai & Predikat & Frekuensi & Persentase \\
\hline $89-100$ & A & 7 & $23 \%$ \\
$79-89$ & B & 5 & $17 \%$ \\
$70-79$ & C & 12 & $40 \%$ \\
$<70$ & D & 6 & $20 \%$ \\
Total & & 30 & 30 \\
\hline
\end{tabular}

Berdasarkan Tabel 10, Hasil belajar lebih dari KKM (70) dimana terdapat 7 (23\%) peserta didik memperoleh predikat nilai A, 5 (17\%) peserta didik memperoleh predikat nilai B dan $12(40 \%)$ peserta didik memperoleh nilai C, serta $6(20 \%)$ peserta didik memperoleh predikat nilai $\mathrm{D}$ yaitu mereka yang nilainya kurang dari KKM.

Kegiatan pembelajaran dilakukan dengan model pembelajaran berbasis proyek yang menuntun peserta didik untuk dapat mengembangkan keterampilan seperti kolaborasi dan refleksi, dapat meningkatkan keterampilan sosial, menjadi lebih percaya diri berbicara dengan kelompok, meningkatkan antusiasme untuk belajar. Ketika anak-anak bersemangat dan antusias tentang apa yang mereka pelajari, mereka sering mendapatkan lebih banyak terlibat dalam subyek dan kemudian memperluas minat mereka untuk mata pelajaran lainnya. Antusias peserta didik cenderung untuk mempertahankan apa yang mereka pelajari, bukan melupakannya secepat mereka lulus tes. Peneliti juga melihat hasil belajar peserta didik dengan nilai yang didapt dari pengerjaan lembar instrument tes berupa soal khususnya pada materi system gerak pada tumbuhan.

Hasil evaluasi untuk keaktifan peserta didik menunjukkan 24 peserta didik (80\%) terlibat aktif sedangkan 6 peserta didik (20\%) lainnya sibuk dengan kegiatan masing-masing, serta pada pelaksanaan pembelajaran dapat dilihat bahwa peneliti sebagai guru sudah mampu menerapkan pembelajaran berbasis proyek. Walaupun dalam kegiatan pembelajaran ditemukan kendala pada guru maupun peserta didik seperti keterbatasan alat, maka setiap kelompok harus bergantian mnggunakan 
alat tersebut. Adapula peserta didik yang masih pasif (belum berani mengemukakan pendapat, mengajukan pertanyaan). Suasana kelas yang ramai membuat guru sebagai fasilitator atau guru dalam membimbing dan mengarahkan menemui kesulitan dalam konumikasi sehingga harus mengulang apa yang telah di jelaskan. Namun hal tersebut bisa diatasi dengan kreativitas guru. Pada proses pembelajaran selanjutnya, terlihat perubahan aktifitas peserta didik yang semakin berani dalam mengemukakan pendapat, ada juga yang berani mengajukan pertanyaan serta keseriusan peserta didik selama proses pembelajaran berlangsung. Hasil analisis untuk hasil belajar peserta didik menunjukan 24 (80\%) peserta didik dinyatakan lulus sedangkan 6 (20\%) peserta didik dinyatakan tidak lulus. Hasil analisis keaktifan peserta didik selama kegiatan pembelajaran dapat dilihat pada Tabel 11.

Tabel 11. Observasi keaktifan peserta didik

\begin{tabular}{lllll}
\hline \multirow{2}{*}{ No } & $\begin{array}{l}\text { Aspek yang } \\
\text { diamati }\end{array}$ & Siklus & II & Peningkatan \\
\hline 1 & Partisipasi & $77 \%$ & $80 \%$ & $3 \%$ \\
2 & Keberanian & $64 \%$ & $66 \%$ & $2 \%$ \\
\multirow{2}{*}{3} & $\begin{array}{l}\text { Kreativitas } \\
\text { belajar }\end{array}$ & $80 \%$ & $95 \%$ & $15 \%$ \\
\hline Rata - rata & $73 \%$ & $80 \%$ & $7 \%$ \\
\hline
\end{tabular}

Berdasarkan Tabel 11, aspek yang mengalami peningkatan tertinggi yaitu aspek kreativitas belajar sebesar 15\%, kemudian aspek partisipasi sebesar 3\% dan aspek keberanian sebesar $2 \%$. Analisis hasil belajar peserta didik selama kegiatan pembelajaran dapat dilihat pada Tabel 12.

Tabel 12 Hasil Belajar Peserta Didik

\begin{tabular}{lll}
\hline \multirow{2}{*}{ Komponen analisis } & \multicolumn{2}{l}{ Siklus } \\
\cline { 2 - 3 } & I & II \\
\hline Nilai terendah & 58 & 64 \\
Nilai tertinggi & 92 & 98 \\
Rata-rata tuntas & $34 \%$ & $80 \%$ \\
Rata-rata tidak tuntas & $66 \%$ & $20 \%$ \\
\hline
\end{tabular}

Berdasarkan Tabel 12, rata-rata ketuntasan hasil belajar mengalami peningkatan dimana untuk yang tuntas pada siklus I dari $34 \%$ menjadi $80 \%$ di siklus II, sedangkan rata-rata yang tidak tuntas pada siklus I dari $66 \%$ menjadi hanya $20 \%$ pada siklus II.

Berdasarkan hasil analisis data dapat dikatakan bahwa proses pembelajaran berbasis proyek terlaksana dengan baik. Dalam proses pembelajaran tersebut yaitu 13 peserta didik (43\%) dikategorikan sangat aktif, 11 peserta didik (36\%) dikategorikan aktif dan 6 peserta didik (20\%) lainnya dikategorikan cukup aktif. Sedangkan hasil analisis untuk hasil belajar peserta didik yakni 6 (20\%) peserta didik tidak lulus/tuntas dan 24 (80\% peserta didik dinyatakan lulus.

Dalam pelaksanaan pembelajaran berbasis proyek inilah dilihat keaktifan peserta didik. keaktifan peserta didik dapat dilihat dari beberapa hal sebagai berikut: 1) Turut serta dalam melaksanankan tugas belajarnya. 2) Terlibat dalam pemecahan masalah. 3) Bertanya kepada peserta didik lain atau guru apabila tidak memahami pesoalan yang dihadapi. 4) Berusaha mencari berbagai informasi yang diperlukan untuk pemecahan masalah. 5) Melaksanakan diskusi kelompok sesuai dengan diskusi guru. 6) Melatih diri dan memecahkan masalah yang sejenis. 7) Kesempatan menerapkan apa yang diperoleh dalam menyelesaikan tugas atau persoalan yang dihadapi.

Hasil penelitian ini relevan dengan penelitian yang telah dilakukan sebelumnya oleh Lestari (2019), dalam hasil penelitiannya ditemukan bahwa penerapan model pembelajaran berbasis proyek terbukti dapat meningkatkan aktivitas siswa, hal ini terlihat dari adanya peningkatan aktivitas belajar siswa. Hasil penelitian lainnya juga dilakukan oleh Arifa, Wibawanto, \& Wirawan (2018) yang menemukan bahwa pembelajaran berbasis proyek dapat meningkatkan metakognitif dan hasil belajar siswa hal ini ditunjukkan dengan adanya peningkatan nilai rata-rata siswa. Kristanti \& Subiki (2017) dalam penelitiannya juga menemukan bahwa aktivitas belajar siswa kelas eksperimen terhadap model pembelajaran berbasis 
proyek dalam pembelajaran juga termasuk dalam kriteria tinggi.

\section{KESIMPULAN}

Berdasarkan penelitian yang dilakukan, maka dapat disimpulkan bahwa pembelajaran berbasis proyek dapat meningkatkan kerjasama anatar peserta didik, dan hasil belajar yang diperoleh peserta didik meningkat dengan adanya penerapan pembelajaran berbasis proyek.

\section{DAFTAR PUSTAKA}

Arifa, A. B., Wibawanto, S., \& Wirawan, I. M. (2018). Penerapan Model pembelajaran project based learning dengan strategi metakognitif untuk meningkatkan metakognitif dan hasil belajar. Jurnal Ilmiah Teknologi Infomasi Terapan, 4(3), 3-7.

Dewi, I. K. A. M. P. (2012). Penerapan model pembelajaran berbasis proyek (project based learning) untuk meningkatkan motivasi dan hasil belajar siswa kelas VIII E pada mata pelajaran teknologi informasi dan komunikasi SMP Negeri 3 Singaraja semester genap tahun ajaran 2011/2012. KARMAPATI (Kumpulan Artikel Mahasiswa Pendidikan Teknik Informatika), 1(5), 992-1005.

Efrimal, F., Kurnia, N., \& Wasidi. (2017). Penerapan model project based learning (PjBL) untuk meningkatkan kecermatan dan kreasi seni rupa. Jurnal Ilmiah Teknologi Pendidikan, 7(2), 48-61.

Kosasih, E. (2014). Strategi belajar dan pembelajaran implementasi kurikulum 2013. Bandung: Yrama Widya.

Kristanti, Y. D., \& Subiki, S. (2017). Model pembelajaran berbasis proyek (project based learning model) pada pembelajaran fisika di SMA. Jurnal Pembelajaran Fisika, 5(2), 122-128.

Lestari, N. (2019). Penerapan model pembelajaran berbasis proyek untuk meningkatkan aktivitas dan hasil belajar siswa kelas V SD Ar-Rahman Misriadi Desa Stabat Lama Langkat. Jurnal Pendidikan dan Pembelajaran Terpadu (JPPT), 1(1), 13-23.
Nurfitriyanti, M. (2016). Model pembelajaran project based learning terhadap kemampuan pemecahan masalah matematika. Formatif: Jurnal Ilmiah Pendidikan MIPA, 6(2), 149160.

Sarwono, S., \& Sugiharto, A. (2017). Pengaruh model pembelajaran project based learning terhadap pengetahuan bencana alam di Indonesia dan perilaku cinta lingkungan hidup siswa kelas X SMA N 2 Surakarta Tahun 2015. Geo Edukasi, 5(1), 184-197.

Wardani, L. (2017). Penerapan model pembelajaran project based learning untuk meningkatkan hasil belajar siswa pada kompetensi dasar membuat kaitan pada benda jadi kelas X Tata Busana SMK Negeri 1 Bojonegoro. Jurnal Tata Busana, 6(3), 12-16.

Wena, M. (2011). Strategi pembelajaran inovatif kontemporer: suatu tujuan konseptual operasional. Jakarta: Bumi Aksara. 